\title{
Discursive Practices and Teaching Mediation to Support Learning in Mathematics and Italian in Primary School from Fenix Program
}

\author{
Daniela Maccario \\ Associate professor of general didactics, \\ University of Turin
}

\begin{abstract}
In order to define teaching principles to be adopted to support learning in Mathematics and Italian in primary school classes starting from the use of Fenix Program, the research was aimed at increasing the knowledge base available through the recognition of good teaching practices from the point of view of teachers in the form of professional routines. In a previous article (Maccario, 2016) we described some findings on the criteria that you can follow in the development of teaching sequences. This article presents a further order of the results concerning the dialogic-discursive structures that represent an important dimension of teaching mediation in accordance with the operational perspective of teachers. Also in this case it is phenomenology which refers to the practical knowledge as a source to be exploited for the construction of teaching principles and scientifically based knowledge in Didactics.
\end{abstract}

Keywords: Research-Development; Didactic Models; Didactic Action; Practical Knowledge; Discursive Practices; Professional Routines.

\section{Introduction}

It is accepted as given that one of the main tasks in pedagogical-didactic research is the elaboration of knowledge to support the professionalisation of lecturers and teachers. Within this view, referring specifically to applied research and research-development (Van der Maren 2014, 2003; Furlong \& Oancea, 2006, 2008), studies aimed at putting in place innovative methodologies and the construction of didactic aids and materials represent a trend that works to consider professional training processes as particularly linked to the acquisition of abilities to analyse and compare practices, to plan and regulate action, and to reflect on personal practices and those of others (Rossi, 2015, pg. 50). One perspective of investigation that seems coherent with these requirements is the elaboration of didactic models such as theoretical-practical devices that may offer those involved outlines based on operative criteria and principles, supporting them in the processes of conceptualisation, analysis and professional self-reflection towards improved self-regulation (Cardarello 2016; Damiano, 2006; 2007). This option implies the recognition of professional practices as the foundation of proposals for educational and didactic innovation and the subject of study that pedagogical-didactic research has to consider, insofar as it is the source of the problems and studied a criteria for the discussion and examination of the capacity of the identified solutions and knowledge (Damiano, 2006). Taking into account these requirements, the article looks at the process and some results of research into the identification of lines of modelling innovative didactic practices starting from the Fenix Programme (Coggi, 2009, 2015) aimed at reinforcing cognitive and educational processes and supporting motivation such as factors to contrast scholastic failure 1 . Among other things, the Programme also proposes the use of games software in the logicalmathematical and linguistic ambits according to curricular progress criteria, in the ambit of didactic courses aimed at students with aspecific learning difficulties; meaning activities undertaken individually or in small groups in laboratories and conducted by specially trained lecturers/mediators. Experiments undertaken in predicted and controlled conditions (Coggi, 2009, 2015) confirmed the Programme's success and a previous study substantially confirmed the possibility of

\footnotetext{
1 The article re-elaborates, develops and completes with brand new results as partially reported in D. Maccario: (2016) Didactic innovation in research perspectives. The Fenix Programme supporting teaching practices. Pedagogical guidelines, (63), 3, pp.519-537; (2017) Didactic models and professionalisation of teachers. Research approaches. In P.G. Rossi (Ed.), Integrating Video into PreService and In-Service Teacher Training (pp.46-64), Hershey PA (USA): IGI Global.
} 
'curricularisation' in ordinary didactic conditions, referring to the management of heterogeneous primary school classes within our national context - (Maccario, 2009); starting with the first 'verification of sustainability', the research ${ }^{1}$ aimed to again test the Programme in the local area (following the 'evaluation chains' logic - Van der Maren, 2014, 2003), in contexts and with subjects in relatively varied operative conditions, with the aim of studying its potential to support the didactic activities while supporting the professional development of the teachers. This research starts from the problem: How to carry out primary school teaching in 'current' didactic conditions to reinforce the cognitive and motivational processes involved in learning in the mathematical-logical and linguistic ambits starting with the Fenix Programme? What may be the structuring steps of a Fenix didactic model supporting teaching activities in 'ordinary' classes? The aim of the study consists in reconstructing elements of didactic modelling implicit in teachers' practices or rather the practical knowledge on how we can teach while making the most of the resources made available by the Programme according to the perspective of those involved. In other words, the attempt to find the phenomenology of those curriculum(s) in fact generated by use of the Programme, that within the general perspective of an activation of a management principle of teaching that aims to promote a personal knowledge elaboration process in the students and stronger autonomous learning and scholastic success. Elsewhere (Maccario, 2006, 2017), some results have been reported that refer to 'good conduct' according to the teachers' perspective, regarding criteria that may be followed in the development of didactic progress (Rey, 2005). This article portrays a further order of results that emerged concerning dialogical-discursive structures that represent an important dimension in didactic mediation according to the teachers' operative perspective; also in this case we are dealing with a phenomenology that refers to the 'knowledge of practices' as a source upon which to define operative principles in the management of didactic mediation.

\section{Theoretic recognition}

Below we refer to the results of the theoretic recognition that has been compared against four subject orders: the collection of elements supporting the hypothesis regarding the relevance of didactic models as constructed by the research to be made available to teachers to allow them to (re)think and act reflectively on the teaching practice and, in this way, innovate it by increasing and developing personal professional skills; the problems, logics and strategic-methodological possibilities of research aimed at constructing didactic models; the problem of identifying categories that allow us to conceptualise and operationalise teachers' didactic activities, considered a cornerstone of their professionalism and subject to study in didactic research.

\subsection{Didactic practices and models}

The usefulness of the didactic models as constructed by the research and made up of formalised outlines to aid teachers to think and enact the practice is greatly accepted (Damiano, 2007), therefore, it is considered possible that this become a subject to be clarified and analysed by those involved, in a process that is fundamental in supporting professional growth. These are theoretic hypotheses that must take on board the procedural nature of those events undertaken and controlled by field operators, usable insofar in that they can be identified by those involved as useful in representing their work (Cardarello, 2016) and understanding it in order to improve it. The recognition of the situated and dynamic character of the teaching processes and professional nature of the teachers' work pushes the concept of the method to pass onto that of the didactic model. The notion of method, generally inferred by knowledge gathered in scientific ambits contiguous to the pedagogical one or rather starting with results of experimentations on the field or, again, from local experience, both individual and group, or by operative implications and militant choices deriving from an adherence to educational ideals, highlights the procedural aspects of the didactic action, in a tendentially prescriptive or recommended interpretation and, implicitly, recognises the teaching practice as a set of applicative behaviour that may be regulated thanks to punctual indications attributed a general value. One of the main difficulties that may be ascribed to this position is the fact that a method - within its ideation and activation phases - cannot be independent from any reference to certain educational contexts and that it cannot be evaluated merely through the appreciation of its effects in absolute. The same method may have contrasting results depending on the situations, the students to whom it is aimed, the teachers and lecturers using it (Bru, 2015). The affirmation of the concept of model can basically be retraced to the recognition of the "knowledge of practices' or rather of the value of the cognitive processes linked to the professional activity - different in nature to the cognitive processes of a more generalising and abstract character. In reference to the didactic practice and, in general, to the professional practice, interpretative hypotheses have been put forward that identify a crucial cognitive aspect in the

1 PRIN 2013- National coordination G. Domenici (Roma Tre University; local coordination C. Coggi, University of Turin). 
processes of 'modellisation' and 'schematisation'. The term 'model' is used to indicate a general mental and schematic representation of a situation that allows those involved to imagine a number of variants, so as to sustain the processes of simulation necessary for the action (Damiano, 2007; Van der Maren, 2014, 2003) in line with the concept of pattern as an organisation of the action that anticipates its goals, rules, possibility to infer in situations, operative invariants, and which allows us to reason and act depending on certain conditions (Vergnaud, 2011; Le Boterf, 2013). Didactic models, when shown to be effective considering the problems and intrinsic nature of teaching, become devices that can support the processes of mental modelisation implicit in practical choices, favouring control thereof. In the very terms of professional didactics (Pastré, 2007), it could be said that the availability of scientifically established didactic models may become a source from which to develop activity models if found they enrich the "cognitive models" instruments available to the teacher as susceptible interpretive keys - in the dialogue with the professional activity - that may support the evolution of the pragmatic schemes used. In other words, we have spoken of the acquisition of teaching skills in terms of didactic patterns (Laurillard, 2012), the development of which may be favoured by a confrontation with general principles that may give it form through reflective processes. The didactic models would therefore become devices to help the operators further understand the situation, with a heuristic function, supporting reflectiveness and ability to make decisions in the moment. A didactic model may be intended as the "simplified representation of operative patterns to undertake educational activities" (Damiano, 1994, pg. 91). It is a construct that refers to the representation of the "action of teaching, in the distinct operations of which it consists, relative to planning-conduction-reflection and which clarify the procedures and respective arguments that justify them" (Damiano, 2007, pg. 71). Within this interpretation, a didactic model is accredited as a teaching theory that serves to optimise the activity, to produce situations and to activate processes that potentially may offer less expensive performance considering the limits of the context. In general, a model includes a reference to the aims or steps of learning that one wishes to follow and selects guide-criteria for the process, offering a simplified representation of didactic events with the intention of saying not 'how should we act', but 'how can we act', taking all operative conditions into account.

\subsection{Strategies of research-development}

Among the theoretic positions constituting a reference point for didactic research into the study of innovative programmes, models and didactic aids, Design Based Research -DBR- is an approach within the Anglophone context that has been accredited with having highlighted, starting with the proposals of Brown and Collins (Brown, 1992; Collins, 1992), the need to take into account the situated character of learning and teaching processes, and to study educational processes and methods for increasing its instructiveness in natural conditions (DBR Collective, 2003; Barab, \& Squire, 2004; Sandoval \& Bell, 2004; Anderson \& Shattuck, 2012). The focus is placed on the applied dimension of pedagogical research, which proposes as a privileged task the elaboration of intervention projects that can support the operators' actions and choices, in the attempt on one hand to overcome the difficulties linked to the large-scale surveying of strictly experimental methodologies, based on controlled inspections that tend, by their very nature, to validate the quality of new methods of intervention by decontextualising them and, on the other hand, the difficulty of ethnographic studies in overcoming the paradigm of descriptiveness and interpretativeness, in order to take on the challenge of transformativity (Pellerey, 2005). The validity of the research consists in knowing how to refer to natural educational conditions, thanks to results that can effectively be used to evaluate, communicate, and increase the effectiveness of the practices within the context being studied and auspiciously in a range of other situations in some way ascribable thereto. The identification and construction of the interventions is a collaborative task taken on by researchers and operators, starting from an understanding of the operative contexts, taking into account the most relevant literature relating thereto, of the pertinent theories and practices used in other contexts, and aims to resolve specific problems or introduce improvements in certain practices (for example, class management, evaluation methods, the use of educational technology, etc.). The collaborative process works on the initial phase to identify the problem, reconstruct the theoretic outline, develop the intervention project and its construction, realisation, evaluation and the creation of theoretic and operative principles. The final phase of DBR research particularly focusses on theoretic comprehension, reflecting the production of planning principles and operative solutions in its comparison with the cognitive legacy available following field experience. Unlike approaches based on research-action, DBR studies are developed not only to fulfil local needs but also to promote theoretical developments concerning problems regarding 'how' to teach and educate. Though this research strategy, conceptualised also as "interventionist ethnography" (Pellerey, 2005, pg. 6), has been the subject of discussion due to a series of difficulties that may be ascribed thereto, especially based on the evidence that it is able to generate, it has become a promising course for having made the importance and significance of educational research relevant again; if within the ambit of the DBR approach we substantially notice the need for coherence in research and its theorisations on educational situations, in order to be considered a 'test- 
bed' of their capacity, other positions refer more directly to the congruence regarding educational activities and practice, identified as a true subject of study, marking, in fact, an ontological turning point. This perspective goes hand in hand with the recognition of the professional character of teaching, causing the research to take on the support of the teachers' activities and professional development as its own elective mandate, with particular focus on the themes of education. Research is increasingly moving towards the 'practice-theory-practice' logic. Referring to the problems of applied research and, more specifically, developed research, the position of Jean Marie Van der Maren (2014) is especially significant within the Francophone ambit; he recognises, together with the progressive recognition of the demand arising from Francophone ergonomics and the paradigm of semplessità (Van der Maren, Yvon, 2009), professional practices as a separate area of study. Regarding the research tasks, the main focus concerns the problem of teachers in actively and knowingly constructing their work, conceptualising and re-conceptualising it, and of disposing of didactic devices - "pedagogical objects" - useful in that way, possibly susceptible to not only local and temporary use but also to being amassed, in relation to their prerequisites, principles and their somehow proven effectiveness. In other words, for researchers, it basically means finding strategies to operationalise ideas and theories that may be of effective use to teachers in their professional activities. A field of research is set up which is validated more on functionality than truth, implying the identification of practicable and incisive solutions, given a group of priorities and limits, of values and contextual customs (organisational, of the local community ....). Because of the complexity that is typical of the situations subject to study and the ruse that characterises the functional practice as a fundamental point of reference, the research may take on a transdisciplinary or transtheoretic character, starting with an "epistemological rupture", a preliminary distancing from preconceptions and already-defined analyses. The criteria of «probability» which requires theories to give a representation of the objects to which they refer professional activities - calls for particular attention to be paid to the coherence of cognitive logics, of the devices used and the nature of the data constructed: the general plans of the subjects' activity must confirm this activity, limiting as much as possible any deformations arising from unsuitable theoretic-conceptual categories or from incongruent instrumentation. From here, even the observation of the inappropriateness of decomposing approaches, which tend towards decontextualisation and the artificial simplification of the situations, to the advantage of basically comprehensive and dynamic interpretations. After all, we are dealing with research that does not tend to elaborate on solutions starting with theories, but rather aims to valorise and develop the solutions the operators have based on their experience. The applied function of the research is associated with a "clinical» approach which implies the participation of those involved in analysing the problems and in the identification of possible answers and solutions. A logic of inspection is configured founded on the theorisation of the practices following a cycle that starts with a description of the activities, distancing itself from them and their specific interrogation, in order to subsequently construct hypotheses and activity outlines 'starting from and relating to the practice'.

\subsection{Didactic activities as a subject of inspection}

Some trends of inspection have in particular thematised the need to identify categories that allow us to operationalise the work of those involved in the situation, restoring the constitutive complexity thereof, so it is clear and can be interpreted in formalised terms. The didactic activity is connoted, in general, in terms of inter-action, which may be surveyed in its contextual dynamicity by observing the recursive dynamics subtended to the manifest variability of the processes. The need for a research approach in which those involved can become subjects of the study processes and experience firsthand the development and sense thereof is confirmed. Enactivist matrix positions (Rossi, 2011; Rossi, Prenna, Giannandrea, \& Magnoler, 2013) (re)propose the notion of a "structural coupling" player-situation to highlight how important it is to study the mutual influence between the teacher's and the student's auto-poietic systems - more than the direct action of one system over the other - regarding the learning tasks. In relative theoretic continuity, the paradigm of simplexity (Poizat, Salini, Durand, 2013), starting with the distinction between prescribed work and actual activity as proposed by the ergonomics of the French language, identifies the acceptance of the implicit complexity of the tasks or working conditions according to methods connoted by astuteness and elegance as a trait that qualifies the professional activity. The structural coupling - the exchanges - between those involved and the context would be characterised by simplexity, which would in turn be supported by processes of "typicalisation", or rather of research into similarities between the current situation and previous experiences within forms of generalisation necessary to the action. Other perspectives, substantially relating to the need to grant a renewed centrality to the student as a 'reality' around which we then construct or should construct within the didactic process, propose we basically conceptualise the action in a conversational key (Pellerey, 2014). The student with his own 'resistances', unexpected answers, his own way of perceiving the world - is the point of reference for the intense activity that the teacher - starting with his own projects, intentions, hypotheses of action - puts into action upon 
seeing it as such; rather than being aimed directly at the student, the teacher directs this activity more to himself in order to establish more suitable possibilities for meetings and support, starting with the subjective and objective-instrumental resources that he deems useful for the purpose. An important cognitive focus is constituted by teacher-students exchanges and amongst the latter to study and understand the teacher's actions in order to set up the suitable conditions for the students' learning through the various types of - direct or indirect - communication to which it may contribute. According to an epistemological perspective of constructionist-Piagetist matrix, the conceptualisation of the didactic action as a "medial action" (Damiano, 2013) refers to the specificity of teacher-student interaction in the scholastic context as a negotiated sharing of learning tasks around cultural subjects, within a dynamic that structures and distinguishes didactic activity from other professional types. The subject of the research is represented by 'what teachers do in relation to what students do in order to learn cultural subjects'. The medial character of the didactic activity indicates that what is in play is not so much a direct knowledge of the world but the comprehension of how others have described and explained it. The construct of 'professional routine' (Damiano 2006; 2013; 2014) as a possible unit of analysis, is put forward to explain the multimensionality and relative unpredictability of teaching, with the inclusion of the space-time and intentional dimensions that constitute them. The routines are to be intended as extremely regular sequences of operations, which allow us to identify the distinctive traits of the didactic activity, a sort of outline leaving the necessary margins for adaptation to take the mutability of the situations into account; these may be subject to study insofar as they are a concentration of what those involved are taught by the processes of reciprocal interaction and adaptation and, on the whole, can be "recognised as the basically unitary structure that characterises teaching, made evident through the corresponding actions" (Damiano, 2014, pg.35). Starting with the near theoretic matrixes, other study trends, essentially ascribable to Francophone professional didactics, propose the "practice organisers" notion, intended as "activity structures" or operatory invariants implicated in professional activities, including teaching (Pastré, 2007; Vergnaud, 2011; Bru M., Pastré P., \& Vinatier, 2007).

\section{Research system}

The research was carried out following some specific steps: 1- training of the research group (researchers, expert Fenix teachers) and identification of the 'trial' schools; 2- research group validation of the problem and objectives; 3- definition of the operative hypothesis and distribution of survey methods; 4 - didactic interventions on the field; 5 - survey and constitution of the databases; 6 - elaboration and discussion. The survey strategy adopted is represented by the case study, according to the logic of multiple cases (Denzin \& Lincoln, 2011; Miles, Huberman, \& Saldaña, 2014) instrumental to this survey and selected to give wider possibility for intensive observation, according to the criteria of relative variability. Specifically, the didactic practices of three highly experienced teachers ${ }^{1}$ were studied; after participating in the initial phase of the study, and wishing to increase their own personal experience in the field, these teachers decided, voluntarily, to make the most of their onsite training, and adopted the Fenix Programme in order to find ways of personalising teaching to new, varying class-contexts. The research involved three schools from the Piedmont area (in the province of Cuneo) in small-medium towns, focussing on students of families living in medium socio-cultural conditions, with a limited number of students per class that the teachers considered as having difficulty in keeping up with the average pace of the class (3-5 students per class), against the overall results of the classes considered in need of improvement regarding learning and motivational autonomy and personal processes required to elaborate knowledge. The didactic activities are undertaken following systematic inflections over a school term. The didactic activities were studied based on the teachers' identification of observational units represented by activities/lessons with a clear beginning, middle and end, so as to make them easily identifiable and unique in representing teaching methods using Fenix activities to those involved. It was therefore expected to acquire a sample group of professional activity of importance for the teachers and relatively undertaken, to then be subjected to intensive observation in order to identify recurring cycles of activities or didactic routines. The study is based on an intensive use of video recordings in normal conditions in order to study the didactic activity - considered in terms of the inter-action between the teacher and students intent in learning and mediated by the multi-media device - according to outlines or activity trends. The use of fixed-camera videos ${ }^{2}$ proved to be not only advantageous insofar as we could return to the processes observed, but also as it ensured good observatory validity allowing us to concurrently take into account the three fundamental polarities - teacher, students, contexts - of the teaching, learning and the dynamic interactions.

\footnotetext{
${ }^{1}$ Stefania Cucco and Alessandra Bettonagli- Didactic management of Mondovi (CN) I Circolo; Anna Maria Cornaglia - Didactic management of Fossano (CN) II Circolo

2 Thanks to the thesis students Debora Allasia, Debora Petté, Roberta Tolosano, students attending the course for a degree in Primary Teaching Sciences in Turin.
} 
Technical limitations, but also and above all the characteristics of the units of analysis - the routines - meant, nevertheless, that other instruments had to also be used (Vander Maren, 2014) such as field notes, focus groups and clarification interviews (Vermesh, 2011): the latter are particularly useful in obtaining a representation of the professional activity that includes not only the "work undertaken" but also the "work adopted" or taken on, or rather the sense that the players construct around their actions (Vander Maren, Yvon, 2009).

Fig.1: Survey Plan

\begin{tabular}{|l|l|l|l|l|l|l|}
\cline { 2 - 7 } \multicolumn{1}{c|}{} & Classes & $\begin{array}{l}\text { Number of } \\
\text { students }\end{array}$ & Subjects & $\begin{array}{l}\text { Total number } \\
\text { of Fenix } \\
\text { lessons }\end{array}$ & $\begin{array}{l}\text { Number of } \\
\text { observatory } \\
\text { lessons }\end{array}$ & Hours \\
\hline CASE A & III A- III B & 32 & $\begin{array}{l}\text { Maths } \\
\text { Italian }\end{array}$ & 7 & 5 & 9 \\
\hline CASE B & II A - II B & 28 & $\begin{array}{l}\text { Maths } \\
\text { Italian }\end{array}$ & 8 & 5 & 12 \\
\hline CASE C & I A - IB & 29 & Maths & 7 & 5 & 10 \\
\hline
\end{tabular}

The video recordings of the lessons and focus groups and the audio recordings of the clarification interviews have been transcribed and codified to allow integrated analysis of the context with the support of the N-Vivo 10 software. The categories are divided up (Miles, Huberman, Saldaña, 2014) based on the unit of analysis represented by didactic routines or recurring cycles of activity through which the teacher aims to promote students' activation in view of the appropriation of cultural objects with the support of the Fenix Programme.

\section{Results}

While an initial level of analysis has found five types of routines corresponding to operative outlines adopted recursively by the teacher-experimenters 'onsite' in 'designing' the sequences of tasks given to students in order to activate processes of cognitive and metacognitive re-elaboration of mathematical and linguistic contents set by the Programme -Rs- (Maccario, 2016), a further perspective of analysis shed light on a different category of recursive structures of didactic mediation referring to the management of dialogic-discursive flows -Rd-. By observing the verbal exchanges in the classroom, in the cases studied and in relation to the Rs recorded, overall we can identify seven activity outlines referring to the communicative exchanges between those involved - teachers and students - as they concentrate on the learning tasks proposed by the Fenix Programme. These dialogic-discursive practices that the teacher uses in order to support and supply the students' cognitive tension and ease the learning process (Lumbelli, 2003) are designed based on the students' response. They are trends that develop within the routines carried out by those involved in the interaction in a continual game of roles and expectations (Selleri, 2016) and which vary depending on the didactic strategies adopted. In this case, within the ambit of group discussions (on the classroom level or between groups of children) or in the teacher-student dialogue, we are looking more at open questions, in which the teacher is able to take on board the students' response and guide the discursive trend towards new cognitive steps (Selleri, 2016; Pontecorvo, 2004). We hereby take a look at and comment briefly on the Rd emerging from an analysis of the textual material obtained from the field studies and broken down into sub-routines (which, unlike the Rs, are not self-consistent). The below view, while inevitably suffering the effects of (hyper)simplification, in terms of linear sequential nature and immobility of the representation, does however offer advantages in the systemisation and clarification of the main logical-practical connections that generate the activity trends. Fig.2: Rd case A

\begin{tabular}{|l|l|}
\hline Rd.0 -Regulation of participation & Rd.1.1- Reactivation and (self)inspection of previous learning. \\
\hline \multirow{4}{*}{ Rd.1-Analysis of delivery } & Rd.1.2- Identification of the task. \\
\cline { 2 - 2 } & Rd.1.3- Operationalisation of the task. \\
\cline { 2 - 2 } & Rd.1.4- Formalisation of the delivery. \\
\hline \multirow{3}{*}{$\begin{array}{l}\text { Rd.2 -Analysis and development of of } \\
\text { operative/thought strategies }\end{array}$} & Rd.2.1- Recognition of work strategies. \\
\cline { 2 - 2 } & Rd.2.2- Formalisation of work strategies. \\
\cline { 2 - 2 } & Rd.2.3- Identification of errors. \\
\cline { 2 - 2 } & Rd.2.4- Identification and analysis of errors. \\
\hline
\end{tabular}




\begin{tabular}{|c|c|c|}
\hline & \multicolumn{2}{|c|}{ Rd.2.5- Identification, analysis, formalisation of errors. } \\
\hline \multirow[t]{8}{*}{ Rd.3- Solution of the problems } & \multicolumn{2}{|c|}{ Rd.3.1- Identification of the problem and its formalisation. } \\
\hline & \multicolumn{2}{|c|}{ Rd.3.2- Launch/taking on of the problem. } \\
\hline & \multicolumn{2}{|c|}{ Rd.3.3- Re-formalisation of the problem. } \\
\hline & \multirow{5}{*}{$\begin{array}{l}\text { Rd.3.4- Exploration and } \\
\text { formalisation of resolutive } \\
\text { strategies }\end{array}$} & Rd.3.4.1-Reflective (self)interrogation. \\
\hline & & Rd.3.4.2 - Re-formalisation of the problem. \\
\hline & & $\begin{array}{l}\text { Rd.3.4.3- Collection-formalisation-analysis of strategic } \\
\text { hypotheses focussed on the problem. }\end{array}$ \\
\hline & & $\begin{array}{l}\text { Rd.3.4.4- Progressive definition of strategies-analyses } \\
\text { focussed on the problem (with re-formalisation)- } \\
\text { possible relaunch. }\end{array}$ \\
\hline & & $\begin{array}{l}R d .3 .4 .5-\text { Formalised ratification of strategies with the } \\
\text { exploration of hypotheses of generalisation. }\end{array}$ \\
\hline
\end{tabular}

From the Rs point of view, Case A shed light on two typical activity outlines both characterised by the operative decision to start the didactic sequence with 'immersive' use of the games by students working in pairs or small groups in a laboratory, with no teacher mediation, and followed by a guided intergroup discussion in the classroom: in one case, in order to analyse the resolutive strategies adopted in order to examine its transferability to other contexts/tasks and, in the second case, as a problematising start directed to the development of new curricular learning (Maccario, 2016). From a viewpoint of the contents of the teacher-student discursive chains we can note, in addition to the recorsivity of exchanges required to favour participation ( $\mathrm{Rd} 0$ ) (diffusive and imbricated with the other Rds), the dialogical confrontation cycles focussed on taking on the delivery (Rd1) which was gradually conceptualised, translated into operative terms and put 'into words' following shared methods, making the effort to adopt the formal language of disciplinary knowledge in play. A further category of communicative cycles can be recognised in relation to the analysis and development of operative and thought strategies implicated by the use of Fenix activities (Rd2); once again, this started with more intuitive recognition and more informal definitions and then led to a description in unambiguously shareable terms, with a focus on the identification, analysis and formalisation of possible errors. Problems resolution evokes a typical dialogical sequence $(R \mathrm{~d} 3)$ that is particularly articulated, with an initial emerging phase in reference to the recognition-analysis-definition of the problem in increasingly strict terms (Rd3.1-2-3) and a subsequent phase (Rd.3.4.), particularly articulated (Rd3.4.1-2-3-4-5), all of which work towards supporting an increasingly less intuitive and more explicitly shared verbalisation of resolutive strategies.

Fig.3: Rd case B

\begin{tabular}{|c|c|c|}
\hline \multirow{15}{*}{$\begin{array}{l}\text { Rd4 - Development of work/learning } \\
\text { strategies. }\end{array}$} & \multicolumn{2}{|c|}{ Rd4.1. Exploration-analysis-formalisation of the delivery. } \\
\hline & \multicolumn{2}{|l|}{ Rd4.2 Reactivation of previous learning. } \\
\hline & \multicolumn{2}{|l|}{ Rd4.3 Guide to taking on the task. } \\
\hline & \multicolumn{2}{|c|}{ Rd.4.4. Clarification and analysis of strategies. } \\
\hline & \multirow{5}{*}{$\begin{array}{l}\text { Rd.4.5 Co-construction/co-analysis of } \\
\text { strategies. }\end{array}$} & Rd.4.5.1 Simulation/prevision. \\
\hline & & Rd.4.5.2 Analysis of difficulties. \\
\hline & & Rd.4.5.3 Exploration of strategies. \\
\hline & & Rd.4.5.4 Identification and analysis of errors. \\
\hline & & Rd.4.5.5 Celebration of success. \\
\hline & \multicolumn{2}{|c|}{ Rd4.6 Regulation/personalisation of rhythms/organisation of the work. } \\
\hline & \multicolumn{2}{|l|}{ Rd4.7 Regulation of interaction. } \\
\hline & \multirow{4}{*}{$\begin{array}{l}\text { Rd4.8. Reconstruction of the work } \\
\text { process. }\end{array}$} & Rd4.8.1 Phenomenological reconstruction. \\
\hline & & Rd4.8.2 (Self)reflective analysis \\
\hline & & Rd4.8.3 (Self)learning outcome. \\
\hline & & Rd4.8.4 Decontextualisation and generalisation. \\
\hline
\end{tabular}

Case $B$ shed light on a unique recursive didactic sequence, in which the teacher and the students - the latter organised in small groups - worked together in a laboratory to develop resolutive strategies to deal with the mathematics and Italian language tasks chosen from those offered by the Fenix Programme (Maccario, 2016). This case also resulted in a rather 
rich discursive phenomenology, moving from a focus on delivery verbalisation (Rd4.1) up to a description of the work process (Rd.4.8), passing through a series of steps regarding the clarification of previous learning, the acceptance of the task, the work strategies (Rd4.2-3-4), with particular discursive activity dedicated to defining shared strategies leading to processes of prediction, the exploration of paths to follow, errors, celebration of successes (Rd4.5.1-2-3-4-5) and the reconstruction of the work process, aimed at defining outcomes in a proactive direction (R.4.8:1-2-3-4).

Fig. 4: Case $\mathrm{C}$

\begin{tabular}{|l|l|}
\hline \multicolumn{2}{|l|}{ Rd.5 - Personalised regulation of rhythms/organisation of the work. } \\
\hline Rd.6- Regulation of interaction. \\
\hline $\begin{array}{l}\text { Rd.7- Reconstruction of the work } \\
\text { process. }\end{array}$ & Rd.7.1-Phenomenological reconstruction. \\
\cline { 2 - 3 } & Rd.7. 2-(Self)reflective analysis. \\
\cline { 2 - 3 } & Rd.7. 3- Learning outcome. \\
\cline { 2 - 3 } & Rd.7. 4 - Decontextualisation and generalisation. \\
\hline
\end{tabular}

The analysis of Case $\mathrm{C}$ brought up a cycle of didactic activities aimed mainly at reinforcing and transferring learning through the experience of differentiated exercises, following 'traditional' approaches alternated with Fenix play-exercises, of further value thanks to the motivating power of the multimedia environment which revisits already-used activities to support the personal elaboration of knowledge in an innovative and evocative key for the children allowing relatively flexible work rhythms and paths (Maccario, 2016). Within the ambit of this type of didactic sequence, as well as the communicative exchanges of an organisational/regulative character (Rd5-6) particular importance is given to the dialogical exchanges between teacher and students regarding the clarification of the work undertaken individually and the analysis thereof in a self-evaluatory and generalising key (R7:1-2-3-4).

\section{Discussion}

In general, routines allow us to implement those didactic practices that the Fenix Programme can supply when used in current teaching conditions, deconstructing them within the perspective of 'action flows with sense' for those involved. The articulated totality of the Rs relative to each case studied represents forms of didactic activity characterised by specific traits, but also by recurring elements. We briefly refer to the latter in relation to the study's aims: the need to restore an integrative cognitive base in order to support teaching through educational games software in schools, in ordinary teaching conditions, in order to outline an integrated set of principles and activity lines to work to help the teachers to renew their practices, even in situations other than those studied. Some points are hereby mentioned. One aspect raised, though limited (case B), by the examples of didactic activities studied concerns the relative indifferentiation of discursive outlines compared to different disciplinary ambits (Italian and mathematics); this is an element for further study but which could induce us to valorise, starting from the perspective of those involved, an approach in which communication in the classroom is set up around Fenix activities in order to support reflection, activating a generative dynamic in which verbal language becomes an essential element to supply and support the development of thought (Pontecorvo, 2004). This interpretation is also affirmed in the intense verbal-communicative activity generated from the reactivation of previous learning, the identification and analysis of errors and constructed learning, and the identification of perspectives of generalisation. Another trait found refers to a distinctive aspect of didactic action as medial action (Damiano, 2013) constituted by the verbalised acceptance of delivery as a decisive step in students managing their own learning (Rey, 2005). In cases A and $B$ in particular, discursive interactions are set up that aim to precisely define and support this step, which therefore is as strategic in Fenix-based teaching management. In other words, teachers' practices seem to testify the need for verbal language mediation at the same rate that multimedia language does immediately, given that it problematizes, in fact, the relationship between informal and formal processes of school learning. The repeated reference to the need to verbalise in the symbolic-formal terms of study disciplines and the logical and learning processes activated and promoted by the use of Fenix software seems to emphasise this need (cases A and B).

\section{Conclusions}

Following in general terms what we had discovered previously (Maccario, 2016), this research seems to indicate the possibility of mediating the Fenix Programme when it is used in current teaching situations, referring to the management of relatively heterogeneous class-groups, in order to promote students' academic success. In addition to a possible, embryonic criteriology for the development of previously outlined didactic sequences - to be refined and enriched (Maccario, 2016), 
the evidence of recurrent dialogic-discursive structures indicates a further trend for development, in the elaboration of increasingly comprehensive didactic models that adhere to the complexity of the teaching activity.

\section{Bibliography}

[1] Anderson T., \& Shattuck J. (2012). Design-Based research: A Decade of Progress in Education Research? Educational Researcher, 41 (1), pp.16-25.

[2] Barab S., \& Squire K. (2004). Design-Based research: Putting a Stake in the Ground. The Journal of the Learning Sciences, 13(1), pp.1-14.

[3] Brown A. (1992). Design experiments; Theoretical and methodological challenges in creating complex interventions in classroom settings. Journal of the Learning Sciences, 2 (2), pp.141-178.

[4] Bru M. (2015). Les méthodes en pédagogie. Paris: PUF.

[5] Bru M., Pastré P., \& Vinatier (Eds.) (2007). Les organisateurs de l'activité enseignante. Perspectives croisées. Recherche et formation pour les professionnels de l'éducation, 56. Paris: INRP.

[6] Coggi C. (Ed.) (2009). Potenziamento cognitivo e motivazionale dei bambini in difficoltà. II Progetto Fenix. Milano: Franco Angeli.

[7] Coggi C. (Ed.) (2015). Favorire il successo a scuola. II Progetto Fenix dall'infanzia alla secondaria. Lecce: Pensa Multimedia.

[8] Collins A. (1992). Toward a design science of education. In E. Scanlon \& T.O'Shea (Eds.), New directions in educational technology (pp.15-22).New York: Springer-Verlag.

[9] Damiano E. (1994). L'azione didattica. Per una teoria dell'insegnamento. Roma: Armando.

[10] Damiano, E. (2006). La nuova alleanza. Temi, problemi, prospettive della Nuova ricerca didattica. Brescia: La Scuola.

[11] Damiano E. (2007). II sapere dell'insegnare. Introduzione alla didattica per concetti con esercitazioni. Milano: Franco Angeli.

[12] Damiano E. (2013). La mediazione didattica. Per una teoria dell'insegnamento. Milano: Franco Angeli.

[13] Damiano E. (2014). Epimeteo. Colui che, avendo fatto, pensa. Una ricerca nella prospettiva dell'attore. In C.Leneve, F.Pascolini, Nella Terra di Mezzo. Una ricerca sui Supervisori del Tirocinio, pp. 23-42. Brescia: La Scuola.

[14] Denzin N., \& Lincoln Y.(2011). The Sage Handbook of Qualitative Research. Los Angeles, London, New Delhi, Singapore, Washington DC: Sage.

[15] Design- Based Research Collective (2003). Design- Based Research: An Emerging Paradigm for Educational Inquiry. Educational Researcher, 1 (32), pp.5-8.

[16] Furlong, J., \& Oancea, A. (2008). Assessing Quality in Applied and Practice-based Educational Research. Continuing the Debate. London and New York: Routledge.

[17] Furlong, J., \& Oancea, A. (2006). Assessing Quality in Applied and Practice-based Educational Research. A Framework for Discussion. Review of Australian Research in Education:Counterpoints on the Quality and Impact of Educational Research, 6, pp. 89-104.

[18] Le Boterf G. (2013). Construire les compétences individuelles et collectives. Paris: Eyrolles.

[19] Laurillard D. (2012). Teaching as a Design Science. Building Pedagogical Patterns for Learning and Technology. New York, $N$ Y: Routledge.

[20] Lumbelli L. (20039). Pedagogia della comunicazione verbale. Milano: Franco Angeli.

[21] Maccario D. (2009). Sostenibilità del Programma Fenix in situazioni didattiche correnti. In C. Coggi (Ed.) (2009). Potenziamento cognitivo e motivazionale dei bambini in difficoltà. Il Progetto Fenix, pp.331-351. Milano: Franco Angeli.

[22] Maccario D. (2016). Innovazione didattica a prospettive di ricerca. II Programma Fenix a supporto delle pratiche d'insegnamento. Orientamenti pedagogici, 3 (63), pp. 519-537.

[23] Maccario D. (2017). Didactic Models and Professionalization of Teachers. In Rossi P.G. (Ed.), Integrating Video into Pre-service and In-service teacher training (pp.46-64). Hershey PA (USA): IGI Global.

[24] Miles M., Huberman M., \& Saldaña J. (2014). Qualitative Data Analysis. A methods Sourcebook. Los Angeles, London, New Delhi, Singapore, Washington DC: Sage.

[25] Pastré P. (2007). Activité et apprentissage en didactique prosessionnelle. In M.Durand- M.Fabre, \& M-Durand, Les situations de formation entre savoir, problems et activité, pp.102-123. Paris: L'Harmattan. 
[26] Pellerey M. (2005). Verso una nuova metodologia di ricerca educativa: la Ricerca basata su progetti (DesignBased-Research). Orientamenti Pedagogici, 5 (52), pp.721-737.

[27] Pellerey M. (2014). La forza della realtà nell'agire educativo. ECPSJournal, 9, pp.63-81.

[28] Poizat G., Salini D., Durand M. (2013). Approche énactive de l'activité humaine, simplexité et conception de formations professionnelles. Education Sciences \&Society, 4 (1), pp.97-112.

[29] Pontecorvo C. (2004). Discutendo s'impara. Roma: Carocci.

[30] Rey, B. (20054). Faire la classe à l'école élémentaire. Paris: ESF.

[31] Rossi P.G. (2011). Didattica enattiva. Complessità, teorie dell'azione, professionalità docente. Milano: Franco Angeli.

[32] Rossi, P.G. (2015). Ripensare la ricerca educativa nell'ottica della professionalità docente e della generalizability. Pedagogia Oggi,(2), pp.49-64.

[33] Rossi P.G., Prenna V., Giannandrea L., \& Magnoler P. (2013). Enactivism and Didactics. Some Research Lines. Education Sciences \&Society, 1, pp.37-57.

[34] Sandoval A., \& Bell P. (2004). Design-Based research methods for Studying Leaning in Context: Introduction. Educational Psychologist, 39 (4), pp.199-201.

[35] Selleri P. (2016). La comunicazione in classe. Roma: Carocci.

[36] Van der Maren, J.-M (2014). La recherché appliquée pour les professionnels. Éducation, (para)medical, travail social. Bruxelles: De Boeck.

[37] Van der Maren, J.-M (2003). La recherché appliqué en Pédagogie. Des modèles pour l'enseignement. Bruxelles: De Boeck.

[38] Van der Maren J.-M, \& Yvon F. (2009). L'analyse du travail entre parole et action. Recherches qualitative, Hors série (7), pp.42-63.

[39] Vergnaud G. (2011). Au fond de l'action, la conceptualization. In J.-M. Barbier, Savoir Théoriques et savoir d'action (pp. 275-292). Paris, France: PUF (Presses Universitaires de France).

[40] Vermesh P. (2011). L'entretien d'explicitation. Paris, France: ESF 